\title{
Self-Representation of Marginalized Groups: A New Way of Thinking through W.E. B. Du Bois
}

\author{
Rashedur Chowdhury \\ University of Southampton
}

\begin{abstract}
I address an interesting puzzle of how marginalized groups gain self-representation and influence firms' strategies. Accordingly, I examine the case of access to lowcost HIV/AIDS drugs in South Africa by integrating W. E. B. Du Bois's work into stakeholder theory. Du Bois's scholarly work, most notably his founding contribution to Black scholarship, has profound significance in the humanities and social sciences disciplines and vast potential to inspire a new way of thinking and doing research in the management and organization fields, including business ethics research. By drawing on Du Bois's works, I argue that through reconstruction of their selves-knowing their souls-marginalized groups know their capabilities better, enabling them to overcome their political and strategic limitations and ensure their true self-representation. They are also empowered to use political imagination and strategies of resistance against more powerful opponents. This influences powerful actors to accept the demands of marginalized groups.
\end{abstract}

Key Words: stakeholder theory, Black scholarship, self-consciousness, social movements and resistance, marginalized stakeholders

$\mathrm{H}$ ow do marginalized groups, which have very limited self-opportunity in institutional settings, influence strategies of multinational corporations (MNCs)? Marginalized groups are generally considered to have hardly any selfrepresentation; they are consistently ignored by powerful actors and are subject to neglect, bias, discrimination, and mistreatment even when they make a meaningful social contribution. Following Du Bois (1903), I define self-representation as having a consciousness and understanding of one's soul and the collective context in which such understanding of "self" resides, whence facts are expressed and freedom and democracy are sought. To be cognizant of the facts and actions necessary to attain freedom, marginalized souls must break free from an ethos of self-pity and deprivation to pursue all available democratic rights, such as freedom of speech, right to protest, and a dignified life in any given context (Du Bois, 1903).

Even though some attempts were made to understand marginalized groups' activities (e.g., Alamgir \& Cairns, 2015; Chowdhury, Kourula, \& Siltaoja, 2018; Derry, 2012; Maher, 2019; Mir, Calas, \& Smircich, 1999; Pal, 2016; Varman \& Al-Amoudi, 2016), we still lack understanding of self-representation and its associated mechanisms through which marginalized souls strive for freedom in the context where MNCs often generate negative and catastrophic outcomes for them.

Business Ethics Quarterly 31:4 (October 2021), pp. 524-548. DOI:10.1017/beq.2021.5 Published by Cambridge University Press on behalf of the Society for Business Ethics.

(C) The Author(s), 2021. 
Such negative outcomes occur because MNCs often collaborate on the basis of colonial mind-set or act on perpetuated colonial legacies of profit maximization strategies with powerful actors, such as elite non-governmental organizations (NGOs) and Western aid agencies and institutions (Chowdhury, 2019a; Chowdhury \& Willmott, 2018; Khan, Munir, \& Wilmott, 2007). MNCs commonly assume that marginalized groups do not have any self-representation for pursuing their concerns because these groups lack sophisticated methods for the articulation of "self" (Chowdhury, 2019b). Such a belief system rooted in epistemic colonial thoughts may then trigger the assumption that non-Western marginalized groups in developing countries need third-party (e.g., aid agencies and elite NGOs) assistance to liberalize (Chowdhury, 2019a; Chowdhury \& Willmott, 2018; Khan et al., 2007). More specifically, based on such assumptions, MNCs collaborate with their powerful stakeholders to set priorities and agendas in the name of rescuing (but in essence further controlling/entrapping) marginalized groups (Chowdhury, 2019a). Khan et al. (2007), for instance, show that with the collaboration of United Nations agencies and foreign NGOs in the Pakistan soccer ball-stitching context, MNCs had framed the problem as abolishing child labor rather than offering these children alternatives for their livelihood or fair wages to their families, an approach that worsened the situation of poor families. An alternative mechanism could have been found and developed if marginalized groups in this context had had access to selfrepresentation to decide their fates and livelihoods in ways that would truly serve their needs. However, such deprivations of self-representation are highly problematic, as many social scientists, historians, and philosophers labor under a concern that asks "Can the non-European think?" (Dabashi, 2015; see also Chakrabarty, 2000; Said, 1978; Spivak, 1988, 1994). This concern highlights the need to reinterpret and re-present past histories and contemporary issues through bias-free scientific inquiries so that better understanding of marginalized groups is established.

More importantly, the preceding concern often leads to life-and-death outcomes for neglected Black and Brown populations, who are subject to trivialization because of the race and biased historiography assigned to them (Cooke, 2003; Cruz, 2014; Ulus, 2018). Chowdhury (2019b) defines trivialization as "ignoring or demonizing the marginalized people of colour in dominant discourse and institutions, so that they feel valueless and disempowered or unrecognized in their everyday life." Du Bois $(1903,1930,1935,1939)$ — a founder of modern sociology and a profound original thinker and philosopher (see the groundbreaking work of Morris [2015] on Du Bois) - analyses this issue more rigorously than anyone else. Lewis (2000: 550) notes that as "the first sociologist of race," Du Bois (1903) conceptualized deeply about race relations, racism, and race and their connection to other sociopolitical conflicts and institutional dominations; for instance, he discusses the contempt and pity that a privileged society assigns to Black persons, which then dictates the type of life they lead. When a group consistently experiences pity or is subject to ignorance and biases, it finds it difficult to participate in epistemic and practical debates or is simply unable to shape a discourse that dominates (cf. Chowdhury, 2017a; Fanon, 1961, 1967; West, 1993). Challenging any status quo becomes harder for this marginalized group. They begin to (albeit subconsciously) unrecognize 
themselves, even though they are full of potential and the capability to make valuable contributions to societal progress (cf. Medina, 2013).

This (re)occurs because the (il)logic of racism and slavery of the past is embedded within the contemporary ethicopolitical structure of our societies (Du Bois, 1896, 1899) — and so the exploitation of marginalized groups continues (Onimode, 1978; Udofia, 1984). By ethicopolitical structure, I refer to epistemic coloniality and practices that are embedded within social, cultural, and political spaces that in effect compound how actors and institutions impose moral problem-solving authority on vulnerable others or draw on their narrow worldview to control and manage their marginalized stakeholders. Said (1978) argues that when trivialization occurs, it is perpetuated not only epistemically (see also Mignolo, 2009) but also through corporatized activities. To counter further trivialization, it is important that Black scholarship emerge organically in the business ethics field and provide an opportunity to reconceptualize issues and actions of marginalized groups through an alternative theorization. This process of reconceptualization should not be seen as an intrusion (or a subject of pity, e.g., Black scholarship needs more space); rather, business ethics must open up alternative voices so that others may record their thoughts without the contempt of or threat from their readers. Such openmindedness would not only enrich business ethics but also show that Western domination of moral philosophy (Dabashi, 2015) is ready to examine deeply rooted causes of racism, oppression, and trivialization of environmental and human degradation that often (un)intentionally impede the lives of marginalized people in deprived parts of the world.

Against this backdrop, I narrate the work of Du Bois to offer a reconceptualization of stakeholder theory. By using Du Bois's work extensively, I attempt to show that marginalized groups (including Black people; minority women; and lesbian, gay, bisexual, transgender, questioning, and/or queer [LGBTQ] groups) also think about, write about, and even resist any types of injustice, including epistemic and practical types. This highlights the importance of self-consciousness (through souls and strivings) that leads to self-representation (cf. Du Bois, 1903, 1935, 1940). I use the South African HIV/AIDS crisis that took place from 1987 to 2001, associated with HIV/AIDS sufferers' (lack of) access to low-cost drugs, as a case example to illustrate Du Bois's argument, where self-representation of HIV/AIDS sufferers, led by the South African Treatment Action Campaign (TAC), eventually influenced thirty-nine pharmaceutical multinationals to change their pricing behavior toward patented HIV/AIDS drugs.

I choose the aforementioned context as a powerful example of how the ways marginalized stakeholders gain self-representation and influence powerful actors are scientifically observable. From this case study, I develop a deeper Du Boisian-based understanding of how marginalized groups gain self-representation and influence MNCs' strategies. I find that marginalized groups' identification of souls and selves in the democratic transformation of their political environment provided them with the opportunity to use their political imagination of strivings. This, in turn, enabled them to use strategic capabilities to reconstruct the very idea of alliances. In the case of HIV/AIDS in South Africa, crucial understanding and mobilization occurred 
because of self-representation that not only influenced MNCs to change the pricing for HIV/AIDS drugs but also established that poor South Africans have just as much right to essential drugs as all other groups. By narrating this process, I make three contributions to stakeholder theory.

First, marginalized groups search for higher morals or self-consciousness despite their vulnerabilities, and when they gain such moral consciousness, they use it for their self-representation. I argue that this process starts at the individual level and aggregates to a collective level where, through political imagination, marginalized groups actively take part in political processes to develop strategic capabilities so that they set their own direction in resisting powerful actors. This also means that when marginalized groups develop their strategic capabilities based on selfconsciousness, they are in a better position to resist the co-option of powerful actors. Co-option is a political process though which an actor impedes the potentials of its opponent(s) to attain its goal (Gargiulo, 1993; Salancik \& Pfeffer, 1978; Selznick, 1949). A marginalized group's resistance toward co-option is imperative because, generally, powerful actors want to set a direction and an agenda for marginalized groups. Therefore various parties collide in jostling to gain prominence by hindering others' potentials or effectiveness. When marginalized groups are self-conscious and self-sufficient, it becomes harder for powerful actors to manipulate these groups on their vulnerabilities, even if they are resource poor.

Second, when marginalized groups self-represent, they can direct powerful actors to participate in (in)formal dialogues and protests either on the marginalized groups' terms or on their behalf. This means that marginalized groups can design and implement strategic actions based on their realities and best possible reasoning and articulation of knowledge-based arguments. In other words, marginalized groups do not just influence powerful actors based on moral claims or by presenting the urgency of their problem but also actively participate in institutional and informal processes where their concerns are taken into consideration because of the influence of their strategic capabilities. These strategic capabilities are actions that powerful actors try to defend or reject, or even develop a negotiation around, to sustain their own legitimacy. In such contested space, self-representation of marginalized stakeholders reinforces their strategic actions because those actions and political maneuvers have more legitimacy than powerful actors' exploitative or manipulative strategies (which powerful actors pursue through co-option). From this perspective, I also add that the stakeholder value creation perspective in stakeholder theory needs to center its focus on marginalized groups' perspectives if issues concern/affect them, rather than observing value creation processes though the lenses of firms or their prominent stakeholders. This is because firms do not address marginalized groups' concerns out of guilt or to fulfill moral claims. Such desire might even never arise unless marginalized groups influence powerful actors to change their behavior or respond to strategic actions developed through self-consciousness.

Third, I find that stakeholder theory often ignores the fact that marginalized groups do not always act based on ideologically motivated actions. In other words, self-consciousness and self-representation are not ideological expressions. Thus, while marginalized groups can be radical or anti-institutionalist, they still negotiate 
and strategically cooperate with actors who are driven by ideologies. However, this is not to infer that marginalized groups are apolitical or without morality; it simply means that morality and self-consciousness lead to effective strategic maneuvers which are transmitted through their members and leaders throughout the confrontation, contestation, and negotiation with powerful actors. Therefore it is essential that marginalized groups develop a solid self and positionality rather than simply reacting based on false stimuli or consciousness that powerful actors try to impose or perpetuate to control and manage these groups.

\section{THEORETICAL CONTEXT}

\section{A Limited Conceptualization of Self-Representation and Strategic Capabilities of Marginalized Groups in Stakeholder Theory}

Stakeholder scholars suggest that primary (e.g., customers and suppliers) and secondary (e.g., communities) stakeholders influence firms in several ways (Frooman, 1999; Frooman \& Murrell, 2005; Hendry, 2005; Sharma \& Henriques, 2005; Zietsma \& Winn, 2008). For example, Frooman (1999) develops a conceptual model on how stakeholders use resources to influence firms' strategic decision-making processes. He argues that primary stakeholders directly influence firm strategies by obstructing/ impeding these firms' access to resources, and secondary stakeholders indirectly influence firm strategies by developing alliances with other powerful stakeholders, who can directly influence firms. Accordingly, Zietsma and Winn (2008) find that, to build an effective alliance, secondary stakeholders with less power and legitimacy use influence chains, such as framing and issue linking, so that networked actors with similar interests provide resources to support them (Rowley, 1997). Hendry (2005), however, finds that while alliance building is important, other factors need to be considered. She posits that secondary stakeholders do not rely on a single type of strategy, such as alliance building, but rather use multiple strategies, such as lobbying and letter-writing campaigns, simultaneously. This argument is apparent in the empirical study of King and Soule (2007), who examine the ways in which secondary stakeholders influence organization processes. They find that through greater media coverage and targeting issues related to primary stakeholders such as employees, secondary stakeholder groups could impact corporations more effectively.

However, despite the specific focus of stakeholder theory in dealing with secondary stakeholders, it fails to adequately examine the issues of marginalized stakeholders and their self-representation. While stakeholder theory assumes the possibility that marginalized groups (portrayed mostly as secondary stakeholders) build alliances with powerful stakeholders to influence firms (Frooman, 1999; Frooman \& Murrell, 2005; Mitchell, Agle, \& Wood, 1997), they also assert that marginalized stakeholders lack leadership and organizing and strategic capabilities to direct alliances - and it is precisely for this reason that powerful stakeholders of firms (e.g., NGOs) represent and direct marginalized groups. This indirectly promotes the idea of trivialization (Chowdhury, 2019b), as it is assumed that firms must give greater consideration to their powerful stakeholders rather than the marginalized ones. This is because the stakeholder salience model (Mitchell et al., 1997), 
which encourages firms to identify salient stakeholders for primary engagement, is still a dominant model in stakeholder literature. Mitchell et al. (1997) argue that the salience of particular stakeholders depends on three attributes: power, legitimacy, and urgency. They stress that stakeholders with all three attributes have a high level of salience, stakeholders possessing only two of these attributes have a moderate level of salience, and stakeholders with only one of these attributes have a low level of salience. However, they do suggest that stakeholders who lack one or two of the three attributes can, through alliances with others who have complementary attributes, achieve a higher level of salience. Therefore, through this model, managers can determine highly salient stakeholders and satisfy the most salient ones by allocating appropriate resources, to the detriment of those less so.

Nevertheless, the stakeholder salience model has some limitations. For example, from a Du Boisian (1903) perspective, this model does not consider higher moral orders that are embedded into self-consciousness or the strength of self-representation of marginalized groups in a dynamic context where these groups are capable of articulating concerns more powerfully than others. Another major shortcoming of this model is that firms can miscalculate or even do not recognize the emotional, strategic, and political moves of marginalized groups (Mansbridge \& Morris, 2001) who are not considered salient stakeholders by firms. For example, in the 1990s, Shell in Nigeria suffered badly because of its alleged involvement with the execution of nine Ogoni activists, including Nobel Peace Prize nominee Ken Saro-Wiwa (Boele, Heike, \& Wheeler, 2001a, 2001b). In addition, owing to persistent pressure from the Ogoni people, Shell subsequently paid US\$15.5 million to Saro-Wiwa's family (Pilkington, 2009) and also ordered compensation of US\$55 million for environmental damage in Nigeria (Vidal, 2015). In another instance, Tata in India was forced to transfer its entire car factory from West Bengal to another part of India as the poor farmers mobilized a successful resistance (Pal, 2016). Similarly, Chowdhury (2019a) shows that Asia Energy, a British mining firm, has long been resisted by poor villagers in Bangladesh; thus, since 2006, a US\$1.1 billion open-pit mining project has been on hold.

The preceding cases reveal that when marginalized groups potentially utilize strategic capabilities, they resist powerful actors who try to misrepresent and co-opt them. This means that, contrary to the skeptical idea that marginalized groups are co-opted in alliance building by firms or their powerful stakeholders (cf. Spivak, 1994), I argue that these groups develop self-consciousness and make use of selfrepresentation to organize and drive strategic capabilities to represent their ideas and activities. If so, a vital scholarly concern is how marginalized groups achieve selfrepresentation, which in turn builds their strategic capabilities (which are generally constrained by various powerful actors and dominant intuitions) to drive forward their agenda on their own terms. This is yet to be comprehensively studied and conceptualized in stakeholder theory.

Overcoming Double-Consciousness Is Core to Mobilizing Freedom and Democracy

Du Bois (1903) famously suggested that to have self-representation and (strategic) capabilities for mobilization against injustices, marginalized groups have 
to overcome double-consciousness. Du Bois defines double-consciousness as follows:

It is a peculiar sensation, this double-consciousness, this sense of always looking at one's self through the eyes of others, of measuring one's soul by the tape of a world that looks on in amused contempt and pity. One ever feels his two-ness,- - an American, a Negro; two souls, two thoughts, two unreconciled strivings; two warring ideals in one dark body, whose dogged strength alone keeps it from being torn asunder (8).

Although Du Bois developed the idea of double-consciousness in the context of the United States, his work is relevant to other countries and contexts, such as South Africa, where Black people are still subject to apartheid legacy, racism, and injustice. This is also because the "problem of the twentieth century" was "the problem of the color line" (see Appiah, 2018; Chandler, 2015), an argument that is still relevant in contemporary societies as the socially constructed race issue continues to divide privileged actors and influences them to make decisions that are inherently racist. Therefore

the question as to how far differences of race-which show themselves chiefly in the color of the skin and texture of the hair-will hereafter be made the basis of denying to over half the world the right of sharing to their utmost ability the opportunities and privileges of modern civilization (Du Bois, cited in Appiah, 2018: 124).

Making use of opportunities or claiming privileges of modern civilization is not easily accessible to marginalized groups in the face of the prejudice they experience due to racial biases. Thus conceptualization of how to overcome doubleconsciousness is the core of my argumentation: what it takes for marginalized groups to strive for freedom when powerful actors embed their colonial epistemic thoughts into institutional structures, marking out a vicious color line to affect the daily lives of such groups. This attempt to overcome double-consciousness reconstructs the very idea of marginalized groups, such as people of color and LGBTQ (Du Bois, 1935). Du Bois argues that one's or a group's history must not be studied without genealogically analyzing the webs of interpretation of those persons or groups. To ensure that a person or group has self-representation, dignities must be protected. Preserving a stakeholder's dignity ensures that he or she has the right to exercise his or her identity (Chowdhury, 2019a). Henceforth, when reconstruction of marginalized groups occurs, we should not simply categorize them as uneducated and incapable people by saying that they live in a developing country or as part of a tribe or by assigning them to a particular race or class. By doing so, we run the risk of inferring that these marginalized groups do not have better understanding than powerful actors to interpret and represent complex issues (cf. Appiah, 2018)—essentially, they have no voice in this process. If this is the case, then marginalized groups do not need to pity themselves or make allowances for prejudice and bias they encounter from the powerful actors (Du Bois, 1903). But such struggle occurs in everyday life and in and around the institutional settings where their souls and strivings are embedded.

Inherently, marginalized groups encounter significant challenges to overcome the stigmas that are embedded into a structure. A Westernized way of development 
means that MNCs are in the position to liberate marginalized groups (Said, 1978). Because marginalized groups do not always enjoy privileges like higher social status or higher-level education, it is assumed they lack clear understanding of their moral claims (cf. Spivak, 1988); for instance, it is assumed they do not understand complex issues of intellectual rights that enable MNCs to produce innovative products and services (cf. Dabashi, 2015). Therefore the strivings for freedom are challenged not only through economic appropriation (such as patents) but also through moral violations. Du Bois (1935) emphasizes that marginalized groups inherited this historical situation because "whiteness" functions as power to exploit Black populations through a capitalist system. This system primarily favors the profitable alliance between capitalists and white workers (Du Bois, 1935). This was very much apparent under the apartheid regime in South Africa. For example, two separate labor laws for whites and Blacks existed during the apartheid period (International Labor Organization, 1964). This meant Black workers did not have collective bargaining power and that Black unions were illegitimate. Moreover, in 1975, Black workers in South Africa's coal mines earned ten times less than white workers due to separatist laws and the dominance of the apartheid regime (Du Roy, 2013). This situation continues as the Rhodes Must Fall movement highlights that Black students and workers are still deprived of better education and work due to institutional dominance of whiteness (Chowdhury, 2019a). For example, University of Cape Town lecturer Xolela Mangcu points out that only five out of the two hundred senior professors at the university are Black (Petersen, 2015).

Du Bois (1935) terms the above a "splendid failure" of reconstruction where scholars often fail to explain the historical background that set the stage for the contemporary suffering of marginalized groups. If such suffering is structured in a way that marginalized groups do not have capabilities to influence a system, then how would they bring about the change they think is righteous and just?

Du Bois (1897) stresses that, without making social reforms or coherently challenging the social laws and regulations (which would serve the interests of marginalized groups), control mechanisms utilized by powerful actors generally perpetuate injustice. For marginalized groups, this is often difficult to fight. Therefore marginalized groups' consciousness of knowledge of moral facts and mobilization of such facts is necessary to influence any powerful actors (cf. Du Bois, 1940). From this perspective, Du Bois (1920) emphasizes that any (un)seen dependency on powerful actors is unwise, as knowledge is politically constructed to benefit the (neo)colonizers.

This means that marginalized groups not only have to mobilize a resistance against injustices by overcoming double-consciousness; they must also ensure that they embed their action plans in scientific knowledge to pursue decolonialization. In other words, Du Bois's conceptualization of overcoming double-consciousness does not rely on emotional reactions (negative/positive); rather, it draws on/from deeply rooted historical/factual, contextual, and knowledge-based ideas embedded into the capability structure of marginalized groups (Du Bois, 1903). 


\section{Leadership Based on Moralist Realism}

Du Bois (1940) suggests that leaders succeed when they adopt a moral realist approach to voice their agendas and devise their actions. Moral realism entails that human actions need to be interpreted through subjective meanings, but at the same time, it is essential to create the necessary conditions for acquiring knowledge of moral facts so that meaningful actions are devised (Du Bois, 1940). In other words, leader have a responsibility to make facts as clear as possible, that is, "the things that actually happened in the world," without imposing their own bias (Du Bois, 1935: 591). To achieve this, leaders often need moral courage to highlight facts that challenge the status quo of powerful actors. This becomes crucial because Du Bois's (1920) concerns over the "self-deception" of leaders in the face of a "new religion of whiteness"-missionaries in Africa, for instance—once provoked the idea that they were there to save the Black population. Instead, they promoted imperialism (Du Bois, 1920). Likewise, certain powerful actors, such as aid agencies and powerful NGOs, wear a veil of deception so that leaders are compromised and cannot take decisive actions. However, Du Bois (1935) thinks that if such courageous moral position is not maintained in resistance, an authentic representation of "the degraded black millions" would be disregarded, and any fight for justice would collapse.

While depicting the facts, Du Bois (1940) predicts the rise of propaganda against Black mobilization of self-representation that strives for freedom. However, if Black souls (standing with their authentic leaders) overcome the continuous contempt and trivialization shown to them by powerful actors, they do not need to suffer from selfinefficiency - thinking they are incapable of influencing powerful actors. Rather, they ought to be self-conscious, knowing they can represent themselves in any challenging discourse and, more importantly, in their everyday lives. This is a holistic self-cultivation process through which Du Bois (1946) rightly suggests securing a wider industrial democracy. Du Bois adds,

More important than political democracy is industrial democracy; that is, the voice which the actual worker, whether his work be manual or mental, has in the organization and conduct of industry (300).

When industrial democracy is achieved, more opportunities to reject the greed and exploitative behavior of powerful actors emerge. Subsequently, exploitation and profit maximization should not remain the main driving forces for any actors. This way, a more equal and just society is possible. In this respect, similar to Marx, Du Bois recognizes that if democracy is established in the industrial context - that is, raw materials, natural resources, land, and technology are not privately owned by only a few privileged actors for profit maximization - then democratic processes should follow to fulfill "the needs of the mass of men" (Du Bois, 1920: 100). Although Du Bois (1935) took Karl Marx's work seriously and called Marx "one of the greatest philosophers of modern times," DeMarco (1983: 192) stresses,

Du Bois's . . . objections to [Marxist] theory and practice involved racial considerations: Blacks formed a special group without a significant class opposition, essentially a proletariat group. Yet blacks were separated from the proletariat movement by racism; 
the proletariat as an economic class was split on racial lines, an eventuality Du Bois viewed Marxism as incapable of explaining.

If so, we need to enquire further how overcoming double-consciousness leads to the development of strategic capabilities that moral realists like Du Bois suggest, particularly in highly contested spaces where marginalized groups are continually subject to accusation of moral and property right violations through the prejudice and bounded color line.

\section{A CASE OF GAINING SELF-REPRESENTATION}

\section{The HIV/AIDS Crisis in South Africa}

The first instance of HIV diagnosis in South Africa was in 1983, and it was found in two homosexual men (Karim \& Karim, 2005). This initial finding of HIV within the homosexual community led to the (misguided) prejudice that AIDS was a "homosexual disease." Believing that it would not affect the wider population, the apartheid government took a passive role. Government officials, however, found themselves in a difficult position when the first HIV cases within the heterosexual population were reported (Grundlingh, 2001). This led the apartheid government to promote condom use. In addition, in the early 1990s, the African National Congress (ANC) launched other initiatives to address the problem, such as the 1992 conference on AIDS jointly organized by the ANC and the government's Department of Health, attended by a wide range of health professionals and activists (Schneider \& Stein, 2001).

During the post-apartheid era, the HIV/AIDS issue started to gain significance. As soon as the Government of National Unity, led by the ANC, won the elections in 1994, it adopted an AIDS Plan (Nattrass, 2006). This democratically elected government declared the issue of the AIDS epidemic as a "presidential-led project" and gave it preferential access to funds (Nattrass, 2006), even though some of the initiatives it undertook were not successful (Rossouw, 1996). In 1997, the South African government, led by President Mandela, passed the Medicines and Related Substances Control Amendment Act of 1965. The main aims of this amendment were to allow compulsory licensing (a country allows firms to produce generic drugs by violating patent restrictions) and/or parallel importation (a country brings generic drugs from third countries by violating patent restrictions) of HIV/AIDS drugs, so that the government could supply cheaper HIV/AIDS drugs to its citizens. Almost immediately, the Pharmaceutical Manufacturers' Association of South Africa (PMA) and major multinational pharmaceutical firms challenged this constitutionally binding act, arguing that it breached South Africa's obligations toward the World Trade Organization and particularly the agreement on Trade-Related Aspects of Intellectual Property Rights. In February 1998, the PMA and forty-two firms filed a lawsuit against the South African government, and in March 2001, after a bitter three-year dispute, the case came to court. In the meantime, the number of applicants suing the government decreased to thirty-nine. 


\section{TAC and the Confrontation with Big Pharma}

On December 10, 1998, International Human Rights Day, while the debate about the Medicines Act of 1997 was ongoing between the South African government and forty-two major pharmaceutical firms, Zackie Achmat, an HIV/AIDS activist, started a local grassroots activist group. Achmat, who has been described as "the most important dissident in the country since Nelson Mandela" (Power, 2003: 54), announced the launch of a new campaign to fight for access to HIV/AIDS treatments under the banner of the National Association of People with AIDS, renamed TAC.

TAC had two main goals: to oppose the portrayal of HIV/AIDS as a "gay plague" (Mbali, 2005) and to achieve access to low-cost medication for HIV/AIDS sufferers. As some of TAC's founding members, including Zackie Achmat, were LGBTQ rights activists, at first TAC tried to fight against the discrimination of LGBTQ individuals as HIV/AIDS carriers. However, while fighting for the rights of the LGBTQ community, TAC discovered that the various relevant government organizations were failing to address the problem of access to low-cost HIV/AIDS drugs. Trying to achieve this became the second major goal of TAC's existence. In other words, as the South African government was incapable of fighting the major pharmaceutical firms effectively to achieve low-cost drugs for its citizens. TAC realized that, in addition to its original fight against the misconception of the HIV/AIDS epidemic, it had to fight for access to affordable HIV/AIDS drugs, so that the sufferers could live productive lives. This meant that TAC had to take on the big pharma firms, which opposed such low-cost access to expensive drugs.

TAC was an informal grassroots organization. Its members would go door to door trying to motivate Black African women to join the organization and fight for access to low-cost HIV/AIDS drugs. The organization had no formal structure or authority; rather, the idea behind the resistance was to informally mobilize marginalized South Africans to fight for their fundamental rights. Most of the women TAC recruited were not politically involved and had no experience in politics or any form of activism, but many of them and their families were affected by HIV/AIDS. Following this informal recruiting strategy, within two years of its launch, TAC was able to attract hundreds of volunteers and thousands of supporters around the country. However, initially, despite its grassroots support, neither the government of President Thabo Mbeki, who replaced Mandela in June 1999, nor the firms engaged with TAC.

Reacting to this marginalization, TAC activists intensified their multifaceted campaign in pursuit of their goals. This campaign included TAC suing the South African government and winning the case in court for not making motherto-child transmission prevention available to pregnant mothers.

One could postulate that this campaign resulted in the appointment of TAC as amicus curiae (friend of the court) during an ongoing court case between the pharmaceutical firms and the South African government. Amicus curiae is an individual or an organization that is not directly involved in the court case but provides the court with relevant information that is not otherwise supplied by litigants (Collins, 2007; Spriggs \& Wahlbeck, 1997). This case was put on hold in 
September 1999 and resumed on March 5, 2001, with TAC being appointed as amicus curiae on March 6. The PMA and the pharmaceutical firms opposed TAC's appointment, which resulted in the delay of the proceedings until April 18, 2001. Then, when the case reopened, before the actual trial, the firms offered to settle out of court, agreed to bear all TAC's legal costs, and adapted their strategies so that lowcost drugs could become available to HIV/AIDS sufferers.

\section{Development of Self-Consciousness}

The TAC case demonstrates that overcoming double-consciousness requires two key processes: 1) understanding of self for political imagination and 2) protest dialogue to actualize self-representation. This implies that TAC was able to strategically mobilize self-consciousness, which means that development of selfconsciousness (i.e., overcoming double-consciousness) and strategic mobilization of self-consciousness are integrated into the processes. Therefore it is important to understand how souls create internal (affect one's selves by questioning oneself) and external (by targeting powerful actors) resistance so that ordinary people do believe they are sufficiently empowered to take strategic actions. In other words, when selves are known by someone striving for freedom, it follows that strategic actions naturally fortify moral claims. It is often difficult for marginalized groups to realize this, but when awareness grows, it is easier for one to overcome doubleconsciousness and simultaneously feel adequate morally, politically, and strategically. In a nutshell, TAC was successful in blending moral and strategic elements into its self-consciousness, which increased its self-effectiveness; subsequently, firms were forced to change their pricing strategies for the distribution of patented HIV/AIDS drugs in South Africa.

\section{Understanding of Selves for Political Imagination}

TAC's understanding of selves and strivings for freedom - that is, ensuring access to HIV/AIDS drugs by all-held merit for three reasons. First, many TAC members (including women of color and LGBTQ people) were HIV/AIDS sufferers, and their accounts of suffering from the disease helped ordinary South Africans and various organizations understand the depth of the crisis. It was a genuine and legitimate representation of pain and suffering, because those talking about the problem were themselves HIV/AIDS sufferers, and their present and future situations were significantly impacted.

There was initial fear that the HIV/AIDS sufferer could not overcome doubleconsciousness because the sufferer is heavily stigmatized on the basis of race, gender, and/or religious beliefs. But by focusing only on the core issue- the unavailability of drugs because of the lack of financial means-TAC emphasized that the crisis regarding access to HIV/AIDS drugs was due to flawed patenting and pricing systems controlled by multinational pharmaceutical firms. Consequently, TAC was able to problematize the issue among different types of affected people to free them from the imprisonment of double-consciousness at an early stage. For this, TAC created street committees so that discussion about access to HIV/AIDS drugs 
not only took place at the personal level but became politicalized and widely discussed in both rural and urban areas. Such politicization was important because their members not only became fully aware of the seriousness of their own suffering but were also activated in a contested space to support TAC's fight against the pharmaceutical firms and help pressure the South African government to be more proactive in making HIV/AIDS drugs affordable (Chowdhury, 2013).

Second, to increase the consciousness of members, TAC repeatedly explained why this issue required urgent attention through scientific information. TAC's use of moral facts emphasized that overcoming double-consciousness is not simply an emotional call; more critically, it is a fact-based argumentation. Moreover, an informant claims (Chowdhury, 2013) that the South African government (led by President Mbeki) "was signing contracts to spend $\$ 11$ billion on weapons that South Africa didn't need and barely uses today," but its response to the HIV/AIDS crisis was that "the country couldn't afford to provide treatment to people living with HIV/AIDS." This indirect denial of essential health care meant that although a fraction of the ANC (ruling party) was unhappy about President Mbeki's behavior toward the HIV/AIDS endemic, it clearly revealed the continuing vulnerability of the poor Black population-even post-apartheid. TAC, thereafter, had a task to reconstruct the need for justice and highlight the real urgency of the case, which gave new momentum to the issue.

Third, TAC was able to imagine that even with limited resources and social infrastructure, it could mobilize a resistance against firms if all its members became self-conscious. One should not forget that not all marginalized groups have the ability to imagine or design a process through which they are able to understand souls better and represent themselves and to influence powerful firms' stakeholders to act on their behalf to pursue a social objective.

TAC realized that it had a strong moral claim to serve not only the deprived Black population but also marginalized women and LGBTQ people, who have long been socially neglected and trivialized in South Africa. This helped them to revitalize their understanding of moral claims to more proactively resist powerful firms. This was crucial because activism for low-cost HIV/AIDS drugs was not a new issue when TAC started its mobilization against the firms. Since 1987, ACT UP in the United States had been actively voicing its concerns about the AIDS crisis. Furthermore, international NGOs and the South African government (led by President Mandela) also expressed concerns about the pharmaceutical firms, but this failed to influence firms' strategies.

Therefore, without this vital self-consciousness, TAC might not have been able to mobilize a political imagination to actualize strategic capabilities that were at the disposal of its ordinary members. By political imagination, I mean a mission to disrupt a dominant system and to compel the powerful actors held responsible to take the low-cost HIV/AIDS drugs crisis seriously. In this case, development of street committees, mobilizing ordinary Black female activists to support the street committees, creating new momentum, and bringing hope to those affected by the HIV/AIDS drugs issue were strategic capabilities that TAC nurtured to persuade powerful stakeholders to support its cause. 


\section{Protest Dialogues to Actualize Self-Representation}

Two types of dialogue took place between TAC and the firms because of protest activities: informal and formal. Informal dialogue took place when TAC sent numerous memoranda, petitions, and letters to firms so that firms had to participate in conversations to defend their strategies by challenging TAC's letters or petitions. Furthermore, by actively challenging firms (via memoranda, petitions, and letters) to enter into dialogue regarding their strategies, some of these firms were influenced to participate in informal meetings with TAC.

TAC presented its case in various public forums, seminars, and governmental meetings, where firms' representatives also participated or presented their cases. For example, on October 28, 2000, the deputy chairperson of TAC, Mark Heywood, presented to the Human Rights, Law, and Ethics Committee of the South African Medical Association on the affordability of essential HIV/AIDS drugs (TAC's founding affidavits). Members of the PMA and Merck were present. This form of informal dialogue helped TAC to pressure the firms to engage in public debate and to invite TAC to participate in formal dialogue. Such (in)formal dialogue between TAC and firms produced some tangible outcomes. For example, at one point, Pfizer decided to donate Diflucan to the South African government. This, however, did not satisfy TAC, because it was "initially limited only to people with AIDS who had cryptococcal meningitis" (TAC press release).

This renewed self-consciousness, or, more precisely, overcoming of doubleconsciousness, also allowed them to believe in themselves as full and righteous actors, worth more than mere donations. They had the courage to ask for their (human and legal) rights and accept nothing less. In other words, TAC did not want firms' pity or philanthropy; rather, it demanded justice and a permanent solution to the problem.

\section{Strategic Mobilization of Self-Consciousness}

TAC was able to effectively mobilize support from various trade unions, political parties, local NGOs, and religious organizations to communicate its conscious messages and set directions for its alliances (Chowdhury, 2013). By doing so, TAC was able to form alliances with firms' powerful stakeholders to make them act on TAC's behalf. Thus TAC was aware of its strategic moves to ensure it retained control of the resistance. This means that, although TAC knew of ideological differentiations among it and various NGOs, TAC influenced or strategically made use of different actors through self-consciousness. For example, although ACT UP's ideological beliefs differed significantly from those of Oxfam and Médecins sans frontières (MSF), TAC strategically allied with international NGOs. Accordingly, it made use of its Act Up connection in the United States during the election campaign of $\mathrm{Al}$ Gore to impose pressure on the US government to influence pharmaceutical firms (Chowdhury, 2013). Additionally, MSF's technical knowledge on health was used to strengthen TAC's understanding of health provisions, but the MSF contribution remained peripheral in the (in)formal setting (Chowdhury, 2013). More notably, prior to the court case (through affidavits), TAC brought the plight of 
HIV/AIDS victims to the public domain, which means that it had moral ground on which to fight its battle. In this battle, neither the CPT nor the South African government had as much claim as TAC because TAC was in charge of leading the movement. Hence TAC's strategic approach to alliance allowed it to work with NGOs without giving them opportunity to manage TAC's activities. Rather, it effectuated in a way that strategic mobilization of self-consciousness was apparent.

\section{DISCUSSION}

We currently have only limited understanding of how marginalized groups gain selfrepresentation and influence firms' strategies in and around institutional settings. Du Bois's work helps to address this puzzle in convincing ways and to generate new theory and new ways of seeing things. More specifically, I find that, contrary to mainstream assumptions and explanations of how marginalized groups are manipulated and co-opted by powerful actors (e.g., for a review, see Burchell \& Cook, 2013), these marginalized groups are able to utilize various powerful MNC stakeholders to act on their behalf. By reconstructing their selves-knowing their soulsmarginalized groups then know how to develop their capabilities better. Overall, this enables marginalized groups to overcome their political and strategic limitations, ensure their true self-representation, and use political imagination and direct strategies of resistance against more powerful opponents. Political imagination is a necessary condition to mobilize protest dialogues and employ other effective uses of strategic resources so that, despite their unwillingness, powerful actors accept the reality of the strivings of marginalized groups. This underscores that marginalized actors are not merely reactionary or irrational groups - a false claim long made against them (cf. Chowdhury, 2019a). Because marginalized groups do not resist powerful actors on a level playing field, often their self-representation is not visible to others. While my findings justify the foregoing arguments, these also more clearly elaborate on Du Bois's work, which is important to interject in business ethics literature. Adoption of his work, more specifically, enables me to make contributions to stakeholder theory. More detailed discussion follows.

Toward a New Theory of Business Ethics: Implications from Du Bois for Moral and Strategic Activities of Marginalized Groups

Through his conceptualization of double-consciousness, Du Bois (1903) indicates the limit of twoness that Black people encounter in their everyday lives in the United States. The twoness that the American Black population encounters is different than that encountered by HIV/AIDS patients in South Africa. In the US case, ancestors of Black people were transported there as slaves. Conversely, the South African Black population was subject to slavery and racism in their own homeland. Such catastrophic moral failures caused Black pain (Chowdhury, 2019b) and uncountable barbaric acts against Black populations (Beckert, 2014). But still, we can easily be trapped within the mind-set that both American and South African people of color suffer from double-consciousness in the same ways; although this is partially true, I further argue that Black South Africans held the most deeply embedded scars of the 
apartheid legacy, which alienated them from mainstream society and economic activity and at the same time exposed them to the pity and mercy of the apartheid regime. Moreover, the struggle to access low-cost HIV/AIDS drugs increased their level of pain tremendously. In Du Bois's (1903) narration, such pain does not have boundaries because, through localization of patenting (a capitalistic mean), MNCs bluntly inflicted their colonial mind-set of profit maximization on the HIV/AIDS sufferers. Therefore global private actors monopolize and colonize the souls of Black folk beyond America, in a far more exploitative manner, given the multifaceted double-consciousness of the Black populations in South Africa. In normal circumstances, we could assume that such suffering would psychologically and physically destroy a marginalized population. However, what is striking is that these HIV/AIDS sufferers were able to overcome their issue of twoness and vulnerability; they were able to show the traits of moral courage and disobedience and thus political imagination to resist powerful actors so that they secured the right to essential lifesaving drugs. By doing so, they not only broke the national boundaries of consciousness; they also impacted the global policy of HIV/AIDS drug pricing.

This shows us that the idea of double-consciousness is not a constant feature of marginalized groups. Marginalized groups at some point detach themselves from the curse of double-consciousness (Du Bois, 1903). This crucially also entails Du Bois's (observable throughout his writing; see Zuckerman, 2004) rejection of narrow psychological or biological explanations of Black populations because a dominant logic of biological superiority of whiteness had long been claimed (see Lester, 1971). In other words, overcoming double-consciousness means that individuals have the ability to take action based on their consciousness and practical abilities, considering the contextual/historical circumstances under which they live or to which they are subject. If so, this has significant implications for dominant structures and institutions (which generally dictate the lives of marginalized groups from a narrow worldview) because, at some point, these groups will challenge the intentions and credibility of those powerful actors who seek to oppress them.

This does not happen simply through an emotional engagement or reactionary behavior (Morris, 2000); rather, it is deeply rooted in history, scientific knowledge, logical reasoning, and argumentation. This is a significant achievement because a general misconception about marginalized groups is that they do not encounter internal power struggles since such groups are heavily dependent on the assistance of external stakeholders (cf. Piven \& Cloward, 1977). In other words, the contention that marginalized groups tend to be ineffective with argumentation in their internal space because debates are only reserved for the elite is simply not true. The moral causes and political emotions are internally actualized in a way that creates desire for powerful actors to support the higher moral claims of marginalized groups. This in effect encourages these groups to make use of these powerful actors so that they do not deviate from their real causes. After all, the end goal is to serve the greater societal well-being.

The preceding discourse means that strategizing the moral position of selves does not equate to unethical behavior. Rather, I call it strategic realism, through which members of an organization fight among themselves to rectify any internal 
confusions or bias, because powerful actors colonize a space like South Africa through color lines and create multiple prejudices to marginalize the Black populations. When their moral purposes are visible - and clear - the unity of such marginalized groups is solidified, and it becomes difficult for powerful actors to dismantle them. At this point, overcoming of double-consciousness is not merely a consciousness freedom; it also ensures sociopolitical freedom. Otherwise, the intended meaning of Du Bois's work is lost. This is because Du Bois (1940) emphasizes the need for moral facts of knowledge so that strategic realism is achieved. Du Bois (1903) does not simply encourage marginalized groups to remove the "veil" of sorrow and guilt that Black people often carry in their daily lives-or at least the veil that powerful actors want Black people to wear so that marginalized groups do not become self-conscious, self-reliant, and self-organizing so that they can fight for self-representation.

Interestingly, materializing strategic realism requires organic leadership. By organic leadership, I mean members who naturally strive to work on technical issues to support and maintain resistance activities. Coincidentally, TAC was originally formed with ten members, and Du Bois (1940) discussed the "talented tenth," a metaphorical leadership approach for establishing democratic ideals. Without organic leadership, it is difficult to manage a collective of different activities effectively. This is because when a resistance becomes bigger and members increase, it is important to achieve stability and maintain a flexible organizational structure. However, organic leadership must ensure that such stability and structure do not become entangled with ideological beliefs or yield to the influence of powerful actors because of leadership mistakes, for example, not carrying out adequate technical research on an issue (Du Bois, 1940). This is, however, a major challenge for any leader of a marginalized group, because they encounter colossal challenges and opposition from powerful actors. Despite this, marginalized groups manage multiple internal and external tensions and complexities, and this is impossible to achieve without leaders who are not only technically capable but also ready to show "moral courage and sacrifices" (Du Bois, 1940). Thus I argue that although the leadership approach Du Bois proposed was metaphorical, organic leadership is valuable for resisting an exploitative capitalistic system if deployed consciously and democratically in a contested space.

The foregoing also means that morality of powerful actors is not naturally present; powerful actors are inherently instrumental and co-opt marginalized groups by all available means. Marginalized groups continuously need to strive for freedom and take action so that their quest for moral justice becomes a reality. Only then will they have the chance of self-representing themselves in discourse. This essentially means that business ethics scholars (e.g., Scherer \& Palazzo, 2007) who promote the idea of deliberative democracy are not so realistic in their thinking that MNCs would show moral consciousness and thus instigate a discussion with sufferers or victims to address an injustice. Even when they engage in discussion, it is mostly rhetorical (Dawkins, 2015). Henceforth Du Bois's (1903, 1935, 1940) conceptualization of double-consciousness would completely contradict such narrations (e.g., Scherer \& Palazzo, 2007), because the capitalist nature of MNCs means they tend to perpetuate 
the exploitation of marginalized groups. Subsequently, business ethics scholars must be cautious about their future theory developments because, if issues like these are not considered, we would generate misrepresentations of marginalized groups in theoretical development and practice.

\section{Contributions to Stakeholder Theory}

Marginalized groups' self-representation has profound implications for firms: it limits firms' opportunity to make use of powerful stakeholders (e.g., aid agencies) to control and manage marginalized groups. In this regard, my fundamental argument is that marginalized groups know how to make their own decisions, which can even be intentional and deliberative wherever and whenever necessary, and do not allow relatively powerful stakeholders of firms (e.g., powerful NGOs, government agencies) to dictate marginalized groups' activities and agendas. This entails three important contributions to stakeholder theory.

First, when marginalized groups overcome double-consciousness, this helps them to engage political imagination to resist co-option of powerful actors. On this basis, they make use of souls and strivings to develop strategic resistance capabilities against powerful actors. This essentially means that marginalized groups search for higher morals or self-consciousness through the fight against double-consciousness. They do so because they know that-in Mitchell et al.'s (1997) terms - they do not have power and legitimacy. Even their urgent needs are frequently ignored by MNCs, because urgency can be interpreted discursively or ignored by labeling it as a social construction (Chowdhury et al., 2018). When higher morals are achieved in such a context, this provides legitimacy. Legitimacy gives visibility to marginalized groups. Visibility, then, can help to attract urgent responses. In the context of access to HIV/AIDS drugs, urgency was always present, but until TAC was able to highlight this urgency through political imagination, TAC had no chance to influence firms. Therefore higher morals embedded into self-representation are important for marginalized groups to gain strategic capabilities that they generally lack due to stigmatization or trivialization and color prejudice, which make things much more difficult for them. More importantly, higher morals counterbalance the need for becoming "powerful" as an actor. This is because a marginalized group is highly unlikely to become as powerful as MNCs. Furthermore, the very idea of gaining power leads to manipulative capabilities, and marginalized groups do not intend to use manipulation, unless deemed necessary for greater societal good (Du Bois, 1903). What marginalized groups desire is the ability to initiate and mobilize strategic realist activities to pursue their societal goals. This is a significant contribution to stakeholder theory because stakeholder scholars (Frooman, 1999; Frooman \& Murrell, 2005; Hendry, 2005; Sharma \& Henriques, 2005; Zietsma \& Winn, 2008) downplay the need for marginalized stakeholders to gain strategic capabilities (and often collapse them into a secondary stakeholder categorization; e.g., see Eesley \& Lenox, 2006), even though these are rooted in self-consciousness or higher morals. Stakeholder theorists must explore this perspective further so that 
we are more aware of how marginalized groups use higher morals in both (non) competitive and (un)stable contexts.

If higher morals are only attained through collective action, then one can argue that Black individuals in general do not possess higher morals in their everyday lives. Du Bois (1903), though, would disagree with such an argument; he suggests that often it is not clearly observable that Black persons are disobedient to a dominant institutional structure. Therefore ambiguity exists about the strivings of marginalized people. This ambiguity always acts against Black populations, as they are subject to multiple and nested socio-economic prejudices. Obviously, when these people collectively show grievance against injustices (Mansbridge \& Morris, 2001), what Black people really want or even how they take part in implementation of political imagination becomes clearer. Stakeholder researchers, therefore, need to go beyond the simplistic ideas that powerful actors, including MNCs, naturally assign to intrinsic ethical behavior (Donaldson \& Preston, 1995) when there is limited consciousness and self-representation of marginalized groups. In other words, whether powerful actors act morally depends on the perceptions and responses of the affected stakeholders. There tends to be a lack of moral imagination among powerful actors to rescue marginalized groups from misery. This is a process of contestation and scrutiny though which marginalized groups try to enforce higher moralities in and around institutional structures.

By incorporating Du Bois's (1903) work in stakeholder theory, what also becomes clearer is that stakeholder scholars overemphasize the categorization of groups rather than individuals. In fact, stakeholder theorists do not consider individuals as a unit of analysis. However, through my work, I argue that overcoming double-consciousness is more of an individual effort. Although I interpreted doubleconsciousness in the context of South Africa through the exploration of a marginalized group, essentially, I assumed that unless individuals realize the possibility of overcoming the twoness, overcoming double-consciousness at the group level is impossible. If this contribution is incorporated into stakeholder theory, then stakeholder scholars will need to look beyond groups and organizations as units of analysis. They must explore the strivings and capabilities of individuals to understand how they are catalysts for stakeholder engagement, such as protest dialogues, and for changing firms' behavior. This also means that while firms address collective issues, they ought not to ignore the plights or issues of marginalized individuals. This is because, even if individuals overcome double-consciousness, they do not have sufficient capabilities to take on strategic realist activities individually. They still need to rely on collective resistance to injustices. This, however, does not mean that individual issues do not matter or should not be considered. If that is the case, those individuals would remain silent victims of powerful actors or outdated/orthodox norms, values, and institutions and suffer real damage and pain. That is why I argue that firms have a serious moral duty to address individuals' moral claims. This is something that stakeholder scholars must seriously consider.

Second, my contribution to stakeholder theory contradicts arguments (Spivak, $1988,1994)$ that marginalized groups do not participate effectively in dialogues with powerful actors. While some of the dialogues took place between TAC and MNCs in 
South Africa and London, in other cases, TAC made use of NGOs in negotiation with MNCs. The point of self-representation and participatory access to dialogues is that this process makes a real difference to whether and how a marginalized group influences firms' strategy on their terms. One could argue that self-representation might not always bring success nor necessarily play a major role in impacting firms' strategies. In this regard, I argue that the ability to participate in dialogues at least legitimizes the moral claims of marginalized groups, as firms are forced to recognize these stakeholders for either moral or strategic reasons and participate in dialogues to find a mutually agreed solution.

Stakeholder scholars (e.g., Donaldson \& Dunfee, 1994; Donaldson \& Preston, 1995; Freeman, 1984; Harrison \& Wicks, 2013) emphasize the need to legitimize stakeholder moral claims for stakeholder value creation, but they do not explain how these claims are actualized: when and how firms engage with marginalized groups. My findings suggest that, by recognizing the self-representation of marginalized groups, firms ought to legitimize these stakeholders' moral claims. If they do so, there is a real chance of developing mutually exclusive value creation rather than value creation skewed to firms' leverage points. Because firms do not naturally explore options for marginalized stakeholder value creation, this imposes an extra burden on marginalized groups to influence firms to adopt such value creation activities.

Henceforth I argue that stakeholder theorists need to conduct studies and develop theories from the perspective of marginalized groups, rather than of firms, to ensure that the moral claims of all stakeholders are fulfilled. If stakeholder scholars were to continue to develop theories based on the firms' perspectives, they would in effect violate the moral claims of marginalized groups, even though such violation is unintentional.

Third, some stakeholder researchers are largely concerned with the ideology of stakeholder groups and its implications for the design of mobilization and protest tactics toward firms. For example, den Hond and de Bakker (2007) emphasize that because of ideologically motivated activism, different stakeholder groups' protest tactics toward firms vary significantly. Accordingly, they argue that at the beginning of the deinstitutionalization process,

reformative activist groups employ non-participatory tactics aimed at making symbolic impacts when starting to influence the nature and level of corporate social change activities (913).

In contrast, I suggest that marginalized groups often use non-participatory tactics to create opportunities for dialogues with firms. The implication for stakeholder theory is that marginalized groups that are strategic realists, such as TAC, do not necessarily use sets of predictable (protest) tactics, as suggested by den Hond and de Bakker (see also della Porta \& Diani, 1997; King \& Soule, 2007). Instead, rather than aligning protest tactics with political ideology or reformist and radical perspectives, marginalized groups maintain a strategic realist approach, which enables them to exercise self-representation. This does not mean that marginalized groups are apolitical; rather, such groups are more interested in leveraging strategic resources that 
give them access to policy and institutional settings to secure long-lasting solutions to social problems.

\section{CONCLUSION}

The industrial democracy that Du Bois envisaged and promoted is still a long way from being achieved in contemporary societies (for further insights and future research work, see Chowdhury, 2017b, 2020), as capitalistic ideas derived from colonialism, slavery, and exploitation still permeate and perpetuate racial injustice. Nonetheless, the TAC case gives us hope because of the self-consciousness it developed over time and the way it used self-representation against powerful pharmaceutical firms. This means that marginalized stakeholders can influence powerful actors effectively. Although it is not easy, as marginalized groups encounter so many challenges and biases, my study has tried to highlight some of the key theoretical and practical aspects that can help future scholars to fortify and enhance marginalized groups' moral, political, and strategic claims more vigorously, in business ethics literature and beyond, so that marginalized groups continue to fight for just societies that they can enjoy as equals.

\section{Acknowledgements}

I sincerely thank the special issue editors for their constructive and valuable comments. More specifically, I am indebted to Patricia Werhane, two anonymous reviewers, and Benjamin Siedler for their guidance in improving this article. I also thank R. Edward Freeman and Stelios Zyglidopoulos for our discussions on stakeholder theory and Gregory Hood for introducing me to the works of Du Bois, which have been both inspirational and helpful.

\section{REFERENCES}

Alamgir, F., \& Cairns, G. 2015. Economic inequality of the Badli workers of Bangladesh: Contested entitlements and a "perpetually temporary" life-world. Human Relations, 68(7): 1131-53.

Appiah, K. A. 2018. The lies that bind: Rethinking identity. London: Profile Books.

Beckert, S. 2014. Empire of cotton: A global history. New York: Knopf Doubleday.

Boele, R., Heike, F., \& Wheeler, D. 2001a. Shell, Nigeria and the Ogoni. A study in unsustainable development: I. The story of Shell, Nigeria and the Ogoni peopleEnvironment, economy, relationships: Conflict and prospects for resolution. Sustainable Development, 9: 74-86.

Boele, R., Heike, F., \& Wheeler, D. 2001b. Shell, Nigeria and the Ogoni. A study in unsustainable development: II. Corporate social responsibility and "stakeholder management" versus a rights-based approach to sustainable development. Sustainable Development, 9: 121-35.

Burchell, J., \& Cook, J. 2013. CSR, co-optation and resistance: The emergence of new agonistic relations between business and civil society. Journal of Business Ethics, 115(4): 741-54.

Chakrabarty, D. 2000. Provincializing Europe: Postcolonial thought and historical difference. Princeton, NJ: Princeton University Press. 
Chandler, N. D. 2015. The problem of the color line at the turn of the twentieth century: The essential early essays. New York: Fordham University Press.

Chowdhury, R. 2013. Reconceptualizing the dynamics of the relationship between marginalized stakeholders and multinational firms. Unpublished doctoral dissertation, University of Cambridge.

Chowdhury, R. 2017a. The Rana Plaza disaster and the complicit behavior of elite NGOs. Organization, 24(6): 938-49.

Chowdhury, R. 2017b. Rana Plaza fieldwork and academic anxiety: Some reflections. Journal of Management Studies, 54: 1111-17.

Chowdhury, R. 2019a. (In)sensitive violence, development, and the smell of the soil: Strategic decision-making of what? Human Relations, 74(1): 131-52.

Chowdhury, R. 2019b. From Black pain to Rhodes Must Fall: A rejectionist perspective. Journal of Business Ethics. DOI: 10.1007/s10551-019-04350-1.

Chowdhury, R. 2020. The mobilization of noncooperative spaces: Reflections from Rohingya refugee camps. Journal Management Studies. DOI: 10.1111/joms.12612.

Chowdhury, R., Kourula, A., \& Siltaoja, M. 2018. Power of paradox: Grassroots organizations' legitimacy strategies over time. Business and Society, 60(2): 420-53.

Chowdhury, R., \& Willmott, H. 2018. Microcredit, the corporatization of NGOs and academic activism: The example of Professor Anu Muhammad. Organization, 26 (1): $122-40$.

Collins, P. M., Jr. 2007. Lobbyists before the U.S. Supreme Court: Investigating the influence of amicus curiae briefs. Political Research Quarterly, 60: 55-70.

Cooke, B. 2003. The denial of slavery in management studies. Journal of Management Studies, 40(1): 1895-1918.

Cruz, J. 2014. Memories of trauma and organizing: Market women's susu groups in postconflict Liberia. Organization, 21(4): 447-62.

Dabashi, H. 2015. Can non-Europeans think? New York: Zed Books.

Dawkins, C. 2015. Agonistic pluralism and stakeholder engagement. Business Ethics Quarterly, 25(1): 1-28.

della Porta, D., \& Diani, M. 1997. Social movements: An introduction. Oxford: Blackwell.

DeMarco, J. 1983. The social thought of W. E. B. Du Bois. Lanham, MD: University Press of America.

den Hond, F., \& de Bakker, F. G. A. 2007. Ideologically motivated activism: How activists groups influence corporate social change activities. Academy of Management Review, 32: 901-24.

Derry, R. 2012. Reclaiming marginalized stakeholders. Journal of Business Ethics, 111: 253-63.

Donaldson, T., \& Dunfee, T. W. 1994. Toward a unified conception of business ethics: Integrative social contracts theory. Academy of Management Review, 19: 252-84.

Donaldson, T., \& Preston, L. E. 1995. The stakeholder theory of the corporation: Concepts, evidence, and implications. Academy of Management Review, 20: 65-91.

Du Bois, W. E. B. 1896. The suppression of the African slave trade to the United States of America: 1638-1870. Oxford: Oxford University Press.

Du Bois, W. E. B. 1897. A program for a sociological society. Speech given at Atlanta University to the First Sociological Club.

Du Bois, W. E. B. 1899. The Philadelphia Negro. Oxford: Oxford University Press

Du Bois, W. E. B. 1903. The souls of Black folk. New York: Bantam Classic.

Du Bois, W. E. B. 1920. Darkwater: Voices from within the veil. New York: Washington Square Press. 
Du Bois, W. E. B. 1930. Africa, its geography, people, and products and Africa-Its place in modern history. Oxford: Oxford University Press.

Du Bois, W. E. B. 1935. Black reconstruction in America. Oxford: Oxford University Press.

Du Bois, W. E. B. 1939. Black folk then and now. Oxford: Oxford University Press.

Du Bois, W. E. B. 1940. Dusk of dawn. Oxford: Oxford University Press.

Du Bois, W. E. B. 1946. Color and democracy. Oxford: Oxford University Press.

Du Roy, I. 2013. Remembering French investments in apartheid South Africa. South African History Online. https://www.sahistory.org.za/archive/remembering-french-investmentsapartheid-south-africa-17-december-2013.

Eesley, C., \& Lenox, M. J. 2006. Firm responses to secondary stakeholder action. Strategic Management Journal, 27: 765-81.

Fanon, F. 1961. The wretched of the earth. New York: Grove Press.

Fanon, F. 1967. Black skin, white masks. New York: Grove Press.

Freeman, R. E. 1984. Strategic management: A stakeholder approach. Boston: Pitman.

Frooman, J. 1999. Stakeholder influence strategies. Academy of Management Review, 24: 191-205.

Frooman, J., \& Murrell, A. J. 2005. Stakeholder influence strategies: The roles of structural and demographic determinants. Business and Society, 44(1): 3-31.

Gargiulo, M. 1993. 2-step leverage: Managing constraint in organizational politics. Administrative Science Quarterly, 38(1): 1-19.

Grundlingh, L. 2001. A critical historical analysis of government responses to HIV/AIDS in South Africa as reported in the media, 1983-94. Paper presented at the International AIDS in Context conference, University of the Witwatersrand, Johannesburg.

Harrison, J., \& Wicks, A. 2013. Stakeholder theory, value and firm performance. Business Ethics Quarterly, 23(1): 97-124.

Hendry, J. R. 2005. Stakeholder influence strategies: An empirical exploration. Journal of Business Ethics, 61: 79-99.

International Labor Organization. 1964. Declaration concerning the policy of apartheid of the Republic of South Africa. http://www.ilo.org/public/libdoc/ilo/1964/64B09_ 117_engl.pdf.

Karim, A. S. S., \& Karim, A. Q. (Eds.). 2005. HIV/AIDS in South Africa. Cambridge: Cambridge University Press.

Khan, F., Munir, K., \& Wilmott, H. 2007. A dark side of institutional entrepreneurship: Soccer balls, child labour and postcolonial impoverishment. Organization Studies, 28: 1055-77.

King, B. G., \& Soule, S. A. 2007. Social movements as extrainstitutional entrepreneurs: The effect of protest on stock price returns. Administrative Science Quarterly, 52: 413-42.

Lester, J. 1971. The seventh son: The thought and writings of W. E. B. Du Bois, vol. 1. New York: Vintage Books.

Lewis, D. L. 2000. W. E. B. Du Bois: The Fight for Equality and the American Century, 1919-1963. New York: Henry Holt.

Maher, R. 2019. Pragmatic community resistance within new indigenous ruralities: Lessons from a failed hydropower dam in Chile. Journal of Rural Studies, 68: 63-74.

Mansbridge, J. J., \& Morris, A. 2001. Oppositional consciousness: The subjective roots of social protest. Chicago: University of Chicago Press.

Mbali, M. 2005. Treatment Action Campaign and the history of right-based, patient-driven HIV/AIDS activism. In P. Jones \& K. Stokke (Eds.), Democratising development: 
The politics of socio-economic rights in South Africa: 213-43. Leiden, Netherlands: Koninklijke Brill.

Medina, J. 2013. The epistemology of resistance: Gender and racial oppression, epistemic injustice, and resistant imaginations. Oxford: Oxford University Press.

Mignolo, W. D. 2009. Epistemic disobedience, independent thought and de-colonial freedom. Theory, Culture, and Society, 26(7-8): 1-23.

Mir, R. A., Calas, M. B., \& Smircich, L. 1999. Global tech noscapes and silent voices: Challenges to theorizing global cooperation. In D. Cooperrider \& J. Dutton (Eds.), Organization dimensions of global change: 270-90. London: Sage.

Mitchell, R. K., Agle, B. R., \& Wood, D. J. 1997. Toward a theory of stakeholder identification and salience: Defining the principle of who and what really counts. Academy of Management Review, 22: 853-86.

Morris, A. D. 2000. Reflections on social movement theory: Criticisms and proposals. Contemporary Sociology, 29(3): 445-54.

Morris, A. D. 2015. The scholar denied: W. E. B. Du Bois and the birth of modern sociology. Berkeley: University of California Press.

Nattrass, N. 2006. The moral economy of AIDS in South Africa. Cambridge: Cambridge University Press.

Onimode, B. 1978. Imperialism and multinational corporations: A case study of Nigeria. Journal of Black Studies, 9(2): 207-32.

Pal, M. 2016. Organization at the margins: Subaltern resistance of Singur. Human Relations, 69: 419-38.

Petersen, C. 2015. UCT refusing to hire black professors. Cape Times, March 23.

Pilkington, E. 2009. Shell pays out \$15.5m over Saro-Wiwa killing. Guardian, June 9.

Piven, F. F., \& Cloward, R. A. 1977. Poor people's movements: Why they succeed, how they fail. New York: Pantheon.

Power, S. 2003. Letter from South Africa: The AIDS Rebel. New Yorker, May 19.

Rossouw, R. 1996. Zuma's revenge. Mail and Guardian (Johannesburg), July 26.

Rowley, T. J. 1997. Moving beyond dyadic ties: A network theory of stakeholder influences. Academy of Management Review, 22: 887-910.

Said, E. 1978. Orientalism. London: Penguin.

Salancik, G. R., \& Pfeffer, J. 1978. Social information-processing approach to job attitudes and task design. Administrative Science Quarterly, 23(2): 224-53.

Scherer, A. G., \& Palazzo, G. 2007. Toward a political conception of corporate responsibility: Business and society seen from a Habermasian perspective. Academy of Management Review, 32: 1096-1120.

Schneider, H., \& Stein, J. 2001. Implementing AIDS policy in post-apartheid South Africa. Social Science and Medicine, 52: 723-31.

Selznick, P. 1949. TVA and the grass roots. Berkeley: University of California Press.

Sharma, S., \& Henriques, I. 2005. Stakeholder influences on sustainability practices in the Canadian forest services industry. Strategic Management Journal, 26: 159-80.

Spivak, G. C. 1988. Can the subaltern speak? In C. Nelson \& L. Grossberg (Eds.), Marxism and the interpretation of culture: 271-313. Urbana: University of Illinois Press.

Spivak, G. C. 1994. Responsibility. Boundary 2, 21(3): 19-64.

Spriggs, J. F., \& Wahlbeck, P. J. 1997. Amicus curiae and the role of information at the Supreme Court. Political Research Quarterly, 50: 565-86.

Udofia, O. E. 1984. Imperialism in Africa: A case of multinational corporations. Journal of Black Studies, 14(3): 353-68. 
Ulus, E. 2018. White fantasy, white betrayals: On neoliberal "feminism" in the US presidential election process. Ephemera, 18(1): 163-81.

Varman, R., \& Al-Amoudi, I. 2016. Accumulation through derealisation: How corporate violence remains unchecked. Human Relations, 69(10): 1909-35.

Vidal, J. 2015. Shell announces $£ 55 \mathrm{~m}$ payout for Nigeria oil spills. Guardian, January 7.

West, C. 1993. Race matters. Boston: Beacon Press.

Zietsma, C., \& Winn, M. I. 2008. Building chains and directing flows strategies and tactics of mutual influence in stakeholder conflicts. Business and Society, 47: 68-101.

Zuckerman, P. 2004. The social theory of W. E. B. Du Bois. Thousand Oaks, CA: Sage.

Rashedur Chowdhury (PhD, Judge Business School, University of Cambridge; r.r. chowdhury@soton.ac.uk) is an associate professor at Southampton Business School, University of Southampton, and a Batten Fellow at the Darden Business School, University of Virginia. His thesis, "Reconceptualizing the Dynamics of the Relationship between Marginalized Stakeholders and Multinational Firms," received the Society for Business Ethics Best Dissertation Award in 2014. He has been a visiting scholar at INSEAD, University College Dublin, the University of Virginia, HEC Switzerland, University of the Western Cape, Peking University, and the University of California, Irvine and Berkeley. His recent works focus on the Rana Plaza collapse and the Rohingya refugee crisis in Bangladesh.

This is an Open Access article, distributed under the terms of the Creative Commons Attribution licence (http://creativecommons.org/licenses/by/4.0/), which permits unrestricted re-use, distribution, and reproduction in any medium, provided the original work is properly cited. 